\title{
Chronic wound healing by fetal cell therapy may be explained by differential gene profiling observed in fetal versus old skin cells
}

\author{
Albert-Adrien Ramelet ${ }^{\mathrm{b}, 2}$, Nathalie Hirt-Burri ${ }^{\mathrm{a}, 1,2}$, Wassim Raffoul ${ }^{\mathrm{f}}$, Corinne Scaletta ${ }^{\mathrm{a}, \mathrm{e}}$, \\ Dominique P. Pioletti ${ }^{\mathrm{d}, \mathrm{e}}$, Elizabeth Offord ${ }^{\mathrm{c}}$, Robert Mansourian ${ }^{\mathrm{c}}$, Lee Ann Applegate ${ }^{\mathrm{a}, \mathrm{e}, *}$ \\ ${ }^{a}$ Department of Musculoskeletal Medicine, Cellular Therapy Unit, University Hospital, CHUV, PAV 03, Rm. 121, 1011 Lausanne, Switzerland \\ ${ }^{\mathrm{b}}$ Office of Dermatology and Angiology, Place de Benjamin-Constant 2, 1003 Lausanne, Switzerland \\ ${ }^{\mathrm{C}}$ Nestlé Research Center, Vers-chez-les-Blanc, Switzerland \\ ${ }^{\mathrm{d}}$ Laboratory of Biomechanical Orthopedics, Ecole Polytechnique Fédérale de Lausanne (EPFL-HOSR), Switzerland \\ e Department of Musculoskeletal Medicine, Lausanne, Switzerland \\ ${ }^{\mathrm{f}}$ Service of Plastic and Reconstructive Surgery, University Hospital, Lausanne, Switzerland
}

\section{A R T I C L E I N F O}

\section{Article history:}

Received 9 June 2008

Received in revised form 3 October 2008

Accepted 4 November 2008

Available online 20 November 2008

\section{Keywords:}

Fetal skin

Chronic wounds

Tissue engineering

Gene families

Extracellular matrix

Growth factors

Leg ulcers

\begin{abstract}
A B S T R A C T
Engineering of fetal tissue has a high potential for the treatment of acute and chronic wounds of the skin in humans as these cells have high expansion capacity under simple culture conditions and one organ donation can produce Master Cell Banks which can fabricate over 900 million biological bandages $(9 \times 12 \mathrm{~cm})$. In a Phase 1 clinical safety study, cases are presented for the treatment of therapy resistant leg ulcers. All eight patients, representing 13 ulcers, tolerated multiple treatments with fetal biological bandages showing no negative secondary effects and repair processes similar to that seen in 3rd degree burns. Differential gene profiling using Affymetrix gene chips (analyzing 12,500 genes) were accomplished on these banked fetal dermal skin cells compared to banked dermal skin cells of an aged donor in order to point to potential indicators of wound healing. Families of genes involved in cell adhesion and extracellular matrix, cell cycle, cellular signaling, development and immune response show significant differences in regulation between banked fetal and those from banked old skin cells: with approximately $47.0 \%$ of genes over-expressed in fetal fibroblasts. It is perhaps these differences which contribute to efficient tissue repair seen in the clinic with fetal cell therapy.
\end{abstract}

(c) 2008 Elsevier Inc. All rights reserved.

\section{Introduction}

Considerable interest and research has been dedicated to the understanding of wound healing and the associated process. Whereas adult cutaneous wounds heal more slowly and with scar formation to restore tissue integrity, fetal skin, in utero, is observed to have rapid and scar-less tissue repair characterized by regeneration of an organized dermis with normal appendages and by a relative lack of inflammation. (Beanes et al., 2002; Bullard et al., 2003; Cass et al., 1997; Adzick and Lorenz, 1994; Armstrong and Ferguson, 1995; Dang et al., 2003; Lorenz et al., 1995). Fundamental differences between fetal and adult skin and the fetal and adult skin wound environment may be important in inducing efficient tissue repair. Chronic wounds, more specifically leg ulcers, are a major

\footnotetext{
* Corresponding author. Address: Department of Musculoskeletal Medicine, Cellular Therapy Unit, University Hospital, CHUV, PAV 03, Rm. 121, 1011 Lausanne, Switzerland. Tel.: +41 21314 3150; fax: +41 218878414

E-mail address: Lee.Laurent-Applegate@chuv.ch (L.A. Applegate).

1 Present address: Department of Pediatric Surgery, University Hospital, Lausanne.

2 These authors contributed equally in this study.
}

health concern. Patient's suffering has long been underestimated and recent evaluations of quality-of-life reveal that patients with leg ulcers have complaints that are substantial and similar to those previously reported for patients with chronic obstructive pulmonary disease, osteoarthritis or angina (Kahn et al., 2004). Costs are considerable and were calculated to exceed 0.5 billion euros/year in Germany and the direct cost of leg ulcers in the UK were calculated at 400 million euros a year (Hafner et al., 1999). Similarly in the United States, estimations are as high as 3 billion dollars for treatment of all forms of leg ulcers. Important variables for cost differences between countries are the frequency of bandage changes and duration of time for each bandage change (Ragnarson and Hjelmgren, 2005). Etiological treatment of venous ulcers is mandatory in order to prevent relapse. Compression therapy is the cornerstone of venous ulcer treatment and high rates of healing (up to $83 \%$ in 6 months) may be obtained by different techniques (Booza et al., 2005). However, such results are not obtained by all teams, and considerable biases of recruitment do exist. In countries with a high standard of health care and a good prevention of venous insufficiency, resistant ulcers are more and more frequent and present as a difficult therapeutic challenge (Chaby et al., 2006; Marklund et al, 2000). 
Local methods for accelerating healing are based on modern wound dressings. However, there is no evidence in the literature that their use really improves the healing rate of venous ulcers (Booza et al., 2005). Therefore, there is an urgent need for new techniques in the treatment of refractory leg ulcers.

New biological therapies for wound healing have significantly advanced including growth factors, skin substitutes, gene and stem cell therapies as well as tissue engineering. The origin of cell choice, their interaction with a biomaterial and the simplicity of preparation is extremely important for eventual therapeutic usage.

Autologous skin fibroblasts and substitutes of various nature have been used on leg ulcers to date (Limat et al., 1996; Uccioli, 2003; Caravaggi et al., 2003; Cavallini, 2007) with different degrees of efficiency. Major drawbacks are that production time is long since patient tissues are necessary for processing. Allogenic skin substitutes using foreskin tissue (Dermagraft ${ }^{\circledR}$, Apligraf ${ }^{\circledR}$ and Or$\mathrm{cel}^{\circledR}$ ) have shown decreased healing times for diabetic foot ulcers, other ulcers and non-weight bearing wounds (Falanga et al., 1998; Marston et al., 2003). The production time is long and we have recently shown high differences in gene expression of banked fetal and foreskin cells used in tissue engineering (Hirt-Burri et al., 2008) which could be, in part, responsible for differences of efficiency seen in the clinic to date.

As banked fetal skin fibroblasts have been previously shown to efficiently induce tissue repair in burns and in acute wounds (Hohlfeld et al., 2005; de Buys Roessingh et al., 2006; Quintin et al., 2007), it was of interest to look at the effect on recalcitrant leg ulcers with different etiologies in the elderly to see if a full clinical trial would be of merit. In this Phase I safety clinical study, we particularly wanted to evaluate the tolerance of multiple treatments with fetal cell biological bandages and interaction with the chronic wound environment. With these specifically banked fetal skin cells used in tissue engineering, we performed microarray analysis to identify differences on the molecular level between specific gene clusters compared to old skin cells, banked in the same manner, which could give some insight into significant parameters involved in efficient wound healing.

\section{Materials and methods}

\subsection{Skin donations and cell bank synthesis}

Cell lines established in the University Hospital of Lausanne from a fetal skin biopsy at 14 weeks of gestation (14 week male fetal skin;14 wFS) obtained after pregnancy termination with informed and written consent and approval from the local Medical School Ethics Committee. Normal skin from an old male donor ( 75 yr old skin; 75 yOS) was obtained in the Department of Dermatology in the University Hospital of Lausanne from a non-sun-exposed skin site (buttocks) also with informed consent and approval from the Medical School Ethics Committee.

From $1 \mathrm{~cm}^{2}$ skin biopsies, three individual cultures were established from each of the biopsies of $14 \mathrm{wFS}$ and 75 yOS to prepare cell banks including all of the vials of cells necessary for the microarray analysis at passage 3 for each of the 6 cell banks (fetal and aged skin cell banks). Dermal tissue was dissected into $<0.5 \mathrm{~mm}^{3}$ fragments and grown in DMEM supplemented with 10\% FCS and glutamine and the cells were used for experimentation at passage 3. They were grown to confluence before splitting and rinsed twice with PBS and counted.

The detailed procedure has been described previously (de Buys Roessingh et al., 2006) and specific conditions for the study herein are described briefly. The tissue was divided into three, $10 \mathrm{~cm}$ plates with whole tissue fragments $\sim 10$ per plate $\left(<0.5 \mathrm{~mm}^{3}\right)$. Tis- sue culture dishes were previously scored deeply with a sterile scalpel in a check-board pattern under the laminar flow hood. Tissue fragments were placed into the scored plastic regions mincing gently. A small quantity of nutrient media was placed around each fragment to avoid floating of tissues for the first $24 \mathrm{~h}$. Rare floating tissues could be overlaid with a sterile microscope cover slide for the first $24 \mathrm{~h}$ if necessary. Following the first $24 \mathrm{~h}, 8 \mathrm{ml}$ of culture media was added onto each $10 \mathrm{~cm}$ plate and this was changed two times per week before passage. These fragments were grown in DMEM supplemented with only $10 \%$ fetal bovine serum (Hyclone) to help insure a consistent dermal skin cell culture. Cell cultures were grown at $37^{\circ} \mathrm{C}$ in a humidified atmosphere of $95 \%$ air/ $10 \% \mathrm{CO}_{2}$. It is important to mention that any nutrient component necessary for cell culture for clinical trials should have thorough safety requirements and tracing. All animal derived products, such as for fetal bovine serum and trypsin, specific clinical lots of trypsin and gamma irradiated serum that have been tested for adventitious agents should be employed (Quintin et al., 2007).

When cell growth advanced after approximately 1 week for fetal tissues and 2 weeks for adult, dishes of tissue and cells were trypsinized $(0.25 \%$ trypsin- $0.1 \%$ ethylene diaminetetraacetic acid [EDTA]). At this point 20 plates were frozen into individual units in liquid nitrogen for each of the three tissue cultures. Cells were centrifuged at $2000 \mathrm{~g}$ for $15 \mathrm{~min}$ and resuspended in a freezing solution of DMEM $(5 \mathrm{ml})+$ FCS $(4 \mathrm{ml})+$ DMSO (1 ml, Fluka) and frozen in $1 \mathrm{ml}$ aliquots $\left(\sim 5\right.$ million cells) at $-80^{\circ} \mathrm{C}$ in Nalgene Cryo $1^{\circ} \mathrm{C}$ Freezing Container's (Nalgene) to achieve a $-1{ }^{\circ} \mathrm{C} / \mathrm{min}$ rate of cooling and freezing curve. After $24 \mathrm{~h}$, cells were transferred to liquid nitrogen for longer storage. Three independent cell banks for each biopsy of 14 wFS and 75 yOS were prepared (denominated FCB and OCB hereafter for Fetal Cell Bank and Old Cell Bank). We have seen that cells frozen in this manner are capable of being stored for at least 15 years in our laboratory.

\subsubsection{Ethical aspects of working with human fetal cells}

Although there is a high medical support for developing cellular based therapies to reach as many patients as possible, there exists a governing political controversy. Scientists and medical doctors have used fetal tissue since the 1930's as a means to understand cell biology and as an essential tool in the development of vaccines. The 1954 Nobel Prize for Medicine was awarded to immunologists who developed the polio vaccine using cultures of human fetal kidney cells. The drastic change in the political environment changed in 1988 when scientists began using fresh fetal tissue and cells for transplantation into patients with Parkinson's disease. Unfortunately, the Reagan administration (US government) declared a moratorium on all federal funding for fetal tissue research. Advances for fetal cell research were then left only to the "private sector" where there is no medical peer-review of adapted therapies. Indeed, if research on whole-cell bio-processing of many fetal tissues could have continued, there certainly would have been advances in the amount of tissue necessary for developing efficient therapies (such as with fetal skin where only one organ donation is necessary to allow for cellular expansion to develop over 900 million fetal skin constructs). In Switzerland and most countries, the fetal skin is considered as an organ donation by law. This process is highly regulated including federal approval for tissue biopsy, stocking and transplantation and ethics committee approval of the procedure and all information for the donor. Even though termination of pregnancy is legally allowed, there will always be strong opponents which will interfere that the laws and practices can remain patient centered (conditions which permit to end an unwanted pregnancy in the best possible way and without unnecessary suffering). 


\subsection{Fetal dermal skin construct preparation}

Preliminary experiments investigating cell seeding density (from $10^{2}$ to $10^{5}$ cells $\mathrm{cm}^{2}$ ) and growth periods (from 1 to 6 days) on a $9 \times 12 \mathrm{~cm}$ equine collagen sheet of $2 \mathrm{~mm}$ thickness dry weight (TissueFleece $^{\circledR}$, Baxter, Switzerland) were performed in order to determine optimal conditions for fetal skin construct preparation. Fetal cells at passages 3 or 4 were placed in $20 \mathrm{ml}$ media (DMEM containing 10\% FBS) and seeded on the collagen sheet by making small incisions at $2 \mathrm{~cm}$ intervals into the collagen matrix with a sterile, small bored Pasteur pipette. The sheet containing the fetal dermal cells (denominated as fetal skin construct) was placed into a $37^{\circ} \mathrm{C}$ incubator at $95 \%$ relative humidity and $10 \% \mathrm{CO}_{2}$. An additional $30 \mathrm{ml}$ media was added $1 \mathrm{~h}$ later. Fetal skin cell constructs remained at a $2 \mathrm{~mm}$ thickness as the original dry collagen sheets. A seeding density of $5 \times 10^{3}$ cells $/ \mathrm{cm}^{2}$ with cells in passages 3-4 and a growth period of 3 days were employed for the patients in this study.

\subsection{Patient selection, preparation and treatment regimen}

Patients were selected on the basis of a history of having refractory chronic leg ulcers, which did not heal using traditional therapies, such as compression (active and passive), hydrocolloids, autografts, among others. A total of 9 patients were admitted in the study including 13 ulcers total (Average age $=73 \mathrm{Yr}, 4$ males and 5 females). Patients recruited suffered from refractory venous ulcers including ulcers with atrophie blanche. In four of these patients, it was possible to accomplish a thorough investigation, including venous (duplex) and arterial investigations (ABI and duplex). Characteristics of patients are presented in the next section.

At each visit, the chronic ulcers were cleaned with physiological saline. Fibrin and necrotic tissue was removed with a curette. Then, the fetal skin construct was applied to cover the entire wound surface, followed by a gauze impregnated with Vaseline, and, if not contra-indicated (one patient suffered from arterio-venous ulcer), compression therapy with long stretch bandage. Application of constructs was one time a week, followed to 4 days to bandage change. Bandages were then changed every two days (Vaseline gauze). There was no modification of medication, way of living, or compression bandaging throughout the fetal skin construct application.

\subsection{Analysis of gene expression}

Gene expression for approximately 12,500 probes representing known genes and expressed sequence tag (EST) profiling of cultured fetal and old human primary fibroblasts was analyzed.

The RNA was isolated from cultured cells at passage 1 for each of the three cell banks for 14 wFS and 75 yOS using the NucleoSpin, RNA II kit (Marchery-Nagel, Düren, Germany) as described by the manufacturer. The RNA samples were monitored with the Agilent 2100 Bioanalyser, consistently demonstrating high-quality RNA (28S/18S ratio approximately 2, but always less than 3 ). Total RNA $(7 \mu \mathrm{g})$ was converted to biotinylated cRNA as previously described (Mutch et al., 2002), and then hybridized to the Affymetrix human genome U95A chip (Affymetrix UK, High Wycombe) containing about 12,500 probes. The comparison was performed in triplicate with three cell banks established independently from the same biopsies (14 wFS and 75 yOS).

\subsection{Data analysis}

The statistical analyses were performed as reported by Mansourian et al., 2004 with a classical analysis of variance (ANOVA) followed by The Global Error Assessment (GEA). In short, The GEA approach takes advantage of several inherent characteristics of microarrays that results in a robust estimate of the error and in a slightly increased statistical power. The method is based on the assumption that any observed difference between the error of genes similarly expressed is only due to sampling. Therefore, after estimating from an ANOVA the mean square error (MSE) of each probe on the microarray independently, in a second step, a robust MSE is calculated from average MSE of 200 neighboring genes with similar intensity signals. In a third step, a new F statistic is recalculated replacing the MSE of the current gene with the robust MSE with the appropriate number of degrees of freedom (df). Averaging the MSE results in a more robust statistic and the increased number of df results into a slightly increased power. Genes were selected by this method at $\alpha$ level 0.001 . Significant genes, with at least a 1.5 -fold change $\log _{2}$, were classified according to the gene ontology following the criteria of the DAVID (database for annotation, visualization, and integrated discovery) (Dennis et al., 2003). This gene list was subjected to the KEGG database (www.genome.jp/Kegg/tool/colorpathway) for signaling pathways.

\subsection{Reverse transcription and real time-PCR (RT-PCR)}

The results obtained with the Affymetrix Human GeneChip were confirmed by RT-PCR for 12 genes using the same fetal and old fibroblast cell lines.

One microgram of total RNA was reverse transcribed using the StratScript reverse transcriptase enzyme (Stratagene, San Diego, CA) as described by the manufacturer. The thermocycler Biometra T-1 (Bimedicinisch Analytic GmbH, Göttingen) was programmed as follows: $25^{\circ} \mathrm{C} 10 \mathrm{~min}, 37^{\circ} \mathrm{C} 60 \mathrm{~min}$ and $90^{\circ} \mathrm{C} 5 \mathrm{~min}$.

Real time PCR using $160 \mathrm{ng}$ of cDNA were performed with ABI Prism 7000 Sequence Detection System (Applied Biosystem, Foster City, CA). We measure the gene expression of 10 genes using TaqMan ${ }^{\circledR}$ Gene Expression Assays (Applied Biosytems) (Table 1). Measurements were performed in triplicates and results are presented associated with standard deviation of the mean. Relative gene expressions was expressed as $-\Delta \Delta C T\left(\log _{2}\right)$ analyzed with the $2^{-\Delta \Delta C T}$ method by Livak and Schmittgen (2001) and normalized to actin gene.

\section{Results}

\subsection{Preliminary assessment of fetal skin constructs on chronic wounds}

In a total of 9 patients treated with fetal cell therapy from 3 to 31 weeks concerning 13 ulcers, we were able to see 8 ulcers closed completely, 4 with significant amelioration in size but not com-

Table 1

Primers for real time confirmation.

\begin{tabular}{ll}
\hline Gene symbol & Ref of TaqMan ${ }^{\circledR}$ gene expression assays \\
\hline GDF10 & Hs00192033_m1 \\
MDK & Hs00383235_m1 \\
PTN & Hs00171064_m1 \\
DPT & Hs00170030_m1 \\
INBHH & Hs00173582_m1 \\
CDKN1C & Hs00175938_m1 \\
RBP1 & Hs00161252_m1 \\
HLA-DPB1 & Hs00157955_m1 \\
FMOD & Hs00157619_m1 \\
BMP6 & Hs00233470_m1 \\
MMP14 & Hs00237119_m1 \\
MMP1 & Hs00233958_m1 \\
MMP3 & Hs00233962_m1 \\
TNFRSF11B & Hs00171068_m1 \\
Actin- $\beta$ & Hs99999903_m1 \\
\hline
\end{tabular}


plete closure and 1 which was lost to follow-up because the patients estimated that there was a substantial improvement. We present the detail of 4 patients herein as we have completed data including venous (Duplex) and arterial investigations (ABI and duplex) described according to CEAP classification (Eklöf et al., 2004).

\subsubsection{Patient 1}

EF is a very compliant 64 years old female patient, with a history of painful post-thrombotic ulcer for 10 years, consecutive to deep venous system and short saphenous vein insufficiency (CEAP $C_{2,3,4 b, 6 S} E_{S} A_{S 2,3,4} D_{13,14} P_{R}$ ) (Fig. 1, Ulcer 1). Previous auto-grafts and different compression therapies including four layers bandages were of no success.

Immediately following the first fetal skin construct, edema diminished, pain was relieved, and fibrin production elimination was evident. This large, deep and painful ulcer healed rapidly with applications of fetal skin constructs one time per week. At 11 weeks, the larger portion of the ulcer was healed. At one year fol- low-up, patient shows skin that is still atrophic but no presence of scar tissue (Fig. 1, Ulcer 1). A new ulcer presented at the ankle one year later and was also successfully closed rapidly without scar (Fig. 1, Ulcer 2).

\subsubsection{Patient 2}

LG is a 62 years old female patient presenting with post-thrombotic bilateral lipodermatosclerosis and atrophie blanche on the lower legs, with an atypical ulcer on the lateral right lower leg

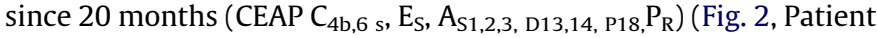
2).

Following fetal cell therapy, the edema and itching immediately disappeared and the original ulcer closed gradually. Because of the fragility of the skin, even though the ulcer of origin was closed a new ulceration occurred at distance from the previous one. For better wound preparation, this patient had the vacuum assisted device (VAC) applied for one week with the intention of applying an autograft. The ulcer and associated minor ulcerations then rapidly

\section{Ulcer 1}
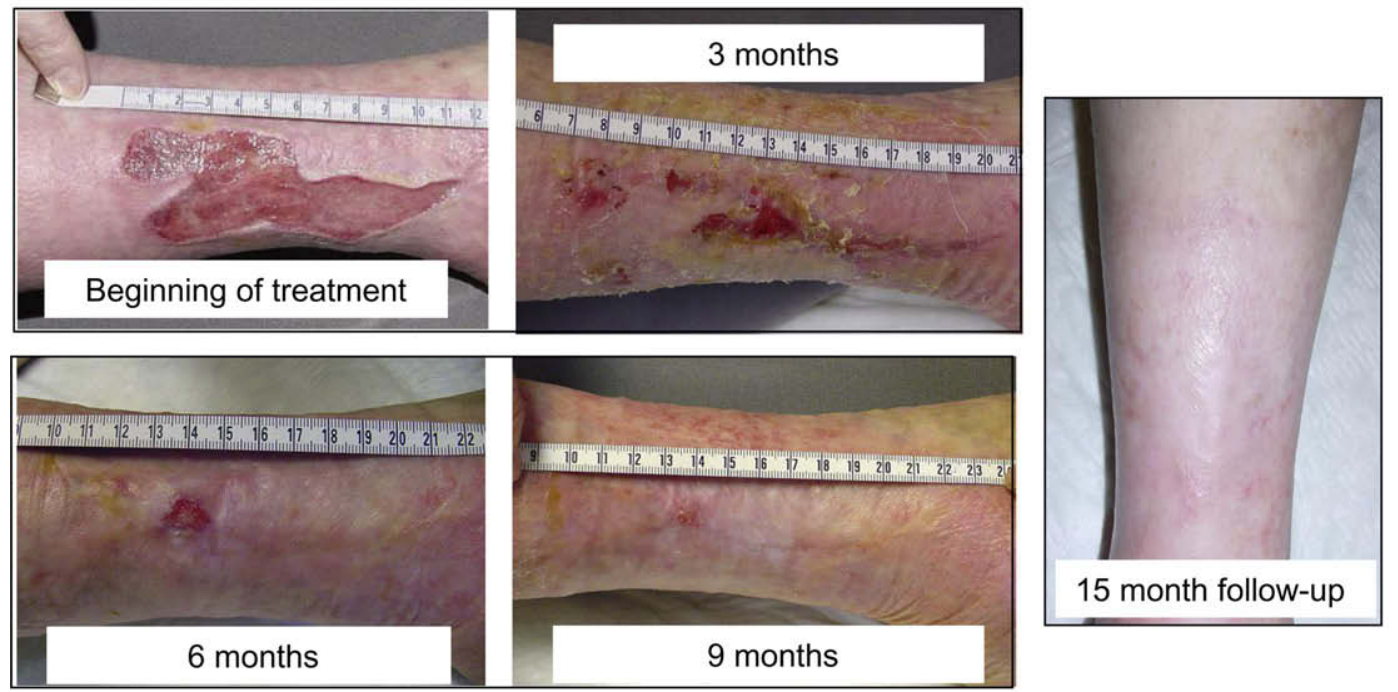

\section{Ulcer 2}
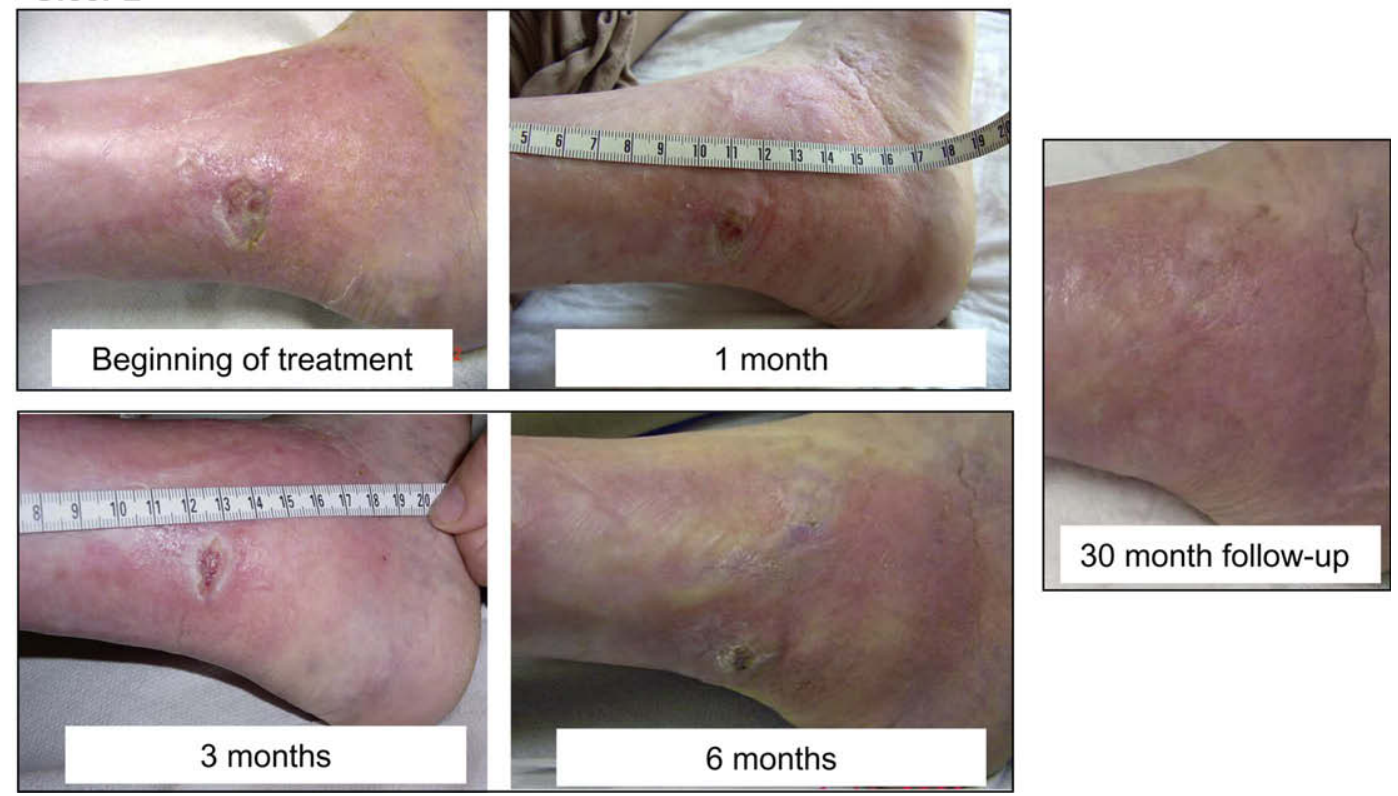

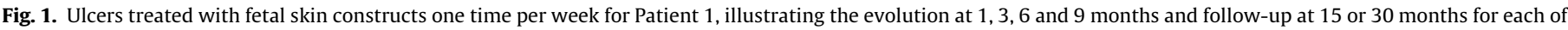
two separate ulcers (Ulcer 1 and Ulcer 2). 

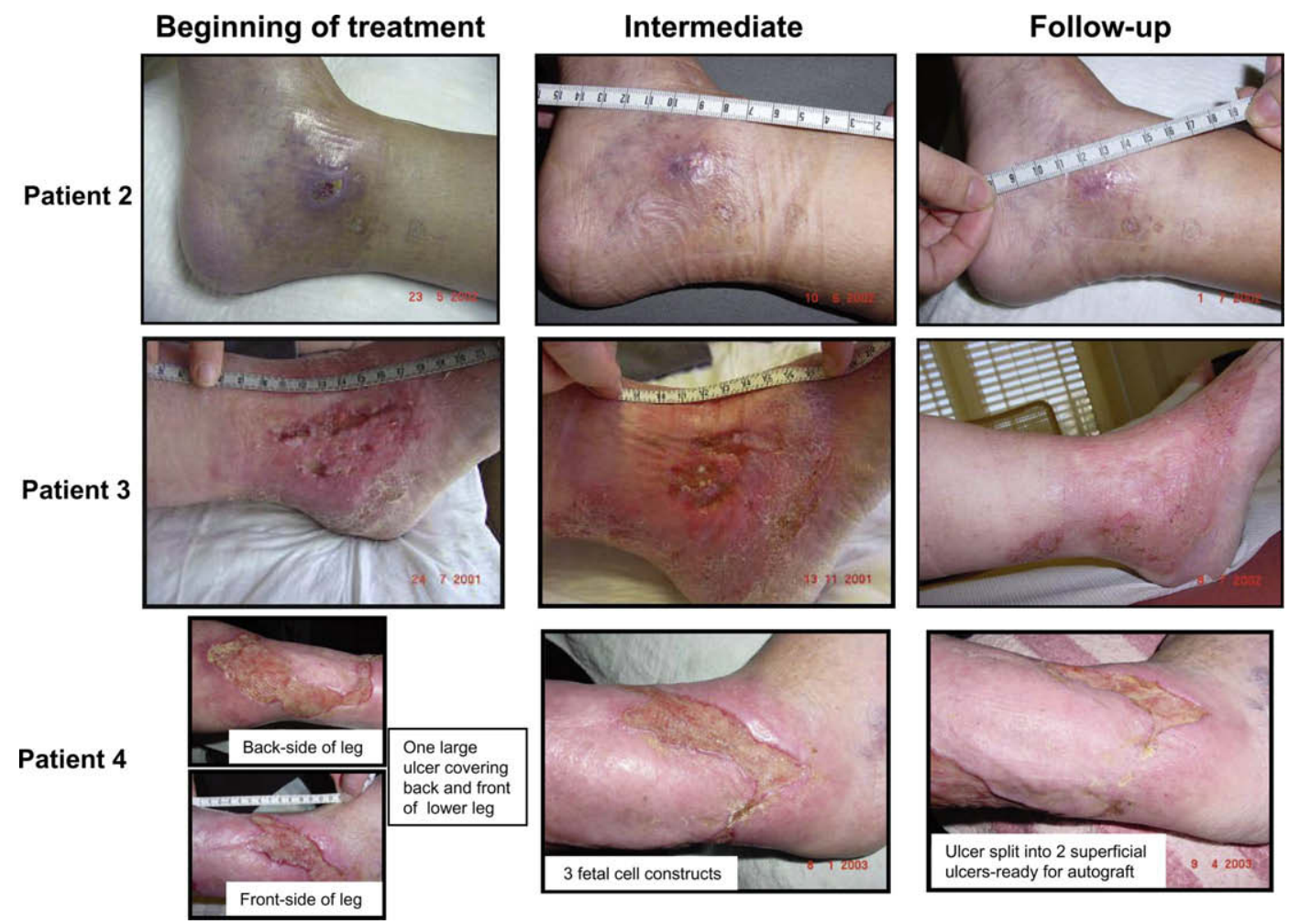

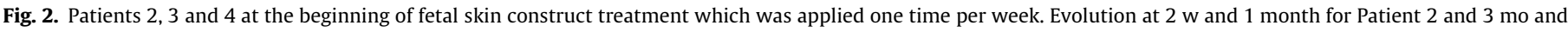

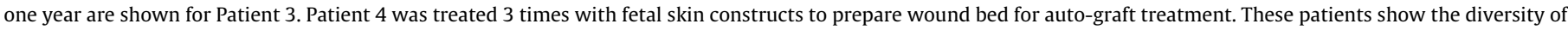
sensitivity of the recalcitrant ulcers treated. Fibrous tissue removal remained pivotal for treatment regimen.

healed with fetal cell application and no auto-graft necessary, which is quite an unusual favorable evolution. Atrophie blanche was stable and no new ulceration developed at the one year follow-up.

\subsubsection{Patient 3}

CC is a 37 years old female patient, suffering since 10 years with a severe post-traumatic post-thrombotic syndrome, with atrophie blanche (Fig. 2, Patient 3). A painful therapy resistant medial malleolar venous leg ulcer developed 2 years ago, consecutive to venous reflux in the deep and superficial venous systems, and leg perforators (CEAP $C_{3,4 b, 6 S} E_{S} A_{S} 2,3,4$ D 13,14,15 $\mathrm{P}{ }_{18} \mathrm{P}_{\mathrm{R}}$ ), aggravated by an arthrodesis of the ankle. Local treatment with fetal cell therapy achieved rapid healing and relieving of pain. However, repetitive inflammatory outbreaks of atrophie blanche in spite of fetal cell treatment or tacrolimus ointment, new superficial post-traumatic ulcerations developed and healed intermittently.

\subsubsection{Patient 4}

RG is an 85 year old male patient suffering global heart failure and severe bilateral knee arthritis presenting with bilateral large ankle ulcers with mild edema and pain over the last 10 years. Vascular investigations were not performed in this case (CEAP $\mathrm{C}_{3,6} \mathrm{~s}$ $\mathrm{E}_{\mathrm{N}} \mathrm{A}_{\mathrm{N}} \mathrm{P}_{\mathrm{N}}$ ) (Fig. 2, Patient 4).

Previous auto-grafts associated to lymphatic drainage and compression therapy allowed temporary wound closure, but recurrence appeared after only a few months each time. Following fetal skin construct application used to prepare the wound bed and to eliminate high fibrin content, auto-grafts were performed on the ulcer site.

Rapidly, wounds healed after one auto-graft application whereas in previous treatments, multiple auto-grafts were necessary for closure with this patient. The wound site was stable during the last two years of the patient's life which was a long period for no recurring ulcers compared to previous years in our clinic.

\subsection{Microarray analysis}

It was of interest to determine gene expression alterations in banked fetal dermal skin cells (used in tissue engineering for burns and wounds to date) and old dermal skin cells that have been banked in the same manner to have a listing of potential gene families from fetal banked cells to compare to old skin cells and other gene profiling studies. To identify differentially expressed genes in banked fetal dermal skin cells, we used cDNA microarray containing approximately 12,500 sequences (U95A human genome chip, Affymetrix UK, High Wycombe). Three arrays were hybridized for banked fetal skin cells and banked old skin cells each. When comparing banked fetal dermal skin cells to banked old fibroblasts with our conditions, 116 genes changed by 1.5 -fold log or more. Between those genes 54 were up-regulated in fetal cells and 62 were down-regulated. Gene Ontology of important differentially expressed genes was annotated following the criteria of the DAVID database (http://david.abcc.ncifcrf.gov/) for annotation, visualization, and integrated discovery) (Dennis et al., 2003). Gene ontologies included apoptosis, cell adhesion, cell-cell signaling, extracellular matrix, transcription factor, cytokine activity and immune response. Many of the genes analyzed could be involved in multiple cellular processes so they have been placed in a category for their best representation. In Table 2, an exhaustive listing of all significantly different regulated genes between Banked Fetal Cells and Banked Old Cells are presented. The majority of genes which are up-regulated in banked fetal dermal skin cells are within cell adhesion and extracellular matrix, (Table 3). The gene list was also confronted with the KEGG database for analysis of signaling pathways. Of the 116 genes, 75 were not included in the data base and 
Table 2

Regulated genes in fetal banked cells compared to old banked cells.

\begin{tabular}{|c|c|c|c|}
\hline Entrez gene ID & Gene symbol & Gene name & Fold increase (expressed in $\log _{2}$ ) \\
\hline 4232 & MEST & Mesoderm specific transcript homolog & 4.598 \\
\hline 2202 & EFEMP-1 & EGF-containing fibulin-like extracellular matrix protein 1 & 4.041 \\
\hline 5947 & RBP1 & Retinol binding protein 1 , cellular & 3.913 \\
\hline 3875 & KRT18 & Keratin 18 & 3.533 \\
\hline 1191 & CLU & Clusterin & 3.511 \\
\hline 5740 & PTGIS & Prostaglandin I2 (Prostacyclin) Synthase & 3.209 \\
\hline 5764 & PTN & Pleiotrophin (Neurite growth-promoting factor 1 ) & 3.050 \\
\hline 55816 & DOK5 & Docking protein 5 & 2.938 \\
\hline 10924 & SMPDL3A & Sphingomyelin phosphodiesterase, acid-like 3A & 2.833 \\
\hline 894 & CCND2 & Cyclin D2 & 2.762 \\
\hline 11341 & SCRG1 & Scrapie responsive protein 1 & 2.718 \\
\hline 59 & ACTA2 & Actin, Alpha 2, Smooth muscle, Aorta & 2.714 \\
\hline 10234 & LRRC17 & Leucine rich repeat containing 17 & 2.676 \\
\hline 7052 & TGM2 & Transglutaminase 2 & 2.657 \\
\hline 4192 & MDK & Midkine (Neurite growth-promoting factor 2) & 2.579 \\
\hline 4781 & NFIB & Nuclear factor $\mathrm{I} / \mathrm{B}$ & 2.508 \\
\hline 1264 & CNN1 & Calponin 1, Basic, Smooth muscle & 2.490 \\
\hline 2331 & FMOD & Fibromodulin & 2.457 \\
\hline 8324 & FZD7 & Frizzled homolog 7 & 2.405 \\
\hline 23089 & PEG10 & Paternally expressed 10 & 2.365 \\
\hline 2149 & F2R & Coagulation factor II (Thrombin) receptor & 2.345 \\
\hline 4628 & MYH10 & Myosin, Heavy polypeptide 10 , Non-muscle & 2.326 \\
\hline 6422 & SFRP1 & Secreted frizzled-related protein 1 & 2.226 \\
\hline 114882 & OSBPL8 & Oxysterol binding protein-like 8 & 2.164 \\
\hline 10643 & IGF2BP3 & Insulin-like growth factor 2 mrna binding protein 3 & 2.143 \\
\hline 8492 & PRSS12 & Protease, Serine, 12 (Neurotrypsin, Motopsin) & 2.124 \\
\hline 1909 & EDNRA & Endothelin receptor type A & 2.095 \\
\hline 65108 & MARCKSL1 & Marcks-like 1 & 2.068 \\
\hline 1000 & $\mathrm{CDH} 2$ & Cadherin 2, Type 1 , N-cadherin & 2.038 \\
\hline 2201 & FBN2 & Fibrillin 2 & 2.034 \\
\hline 2239 & GPC4 & Glypican 4 & 2.034 \\
\hline 2719 & GPC3 & Glypican 3 & 2.021 \\
\hline 23705 & IGSF4 & Immunoglobulin superfamily, member 4 & 2.012 \\
\hline 7472 & WNT2 & Wingless-type MMTV integration site family member 2 & 1.961 \\
\hline 22836 & RНОВТВ3 & Rho-related btb domain containing 3 & 1.881 \\
\hline 9249 & DHRS3 & Dehydrogenase/reductase (SDR family) member 3 & 1.855 \\
\hline 10962 & MLLT11 & Myeloid/lymphoid or mixed-lineage leukemia & 1.795 \\
\hline 5179 & PENK & Proenkephalin & 1.782 \\
\hline 1466 & CSRP2 & Cysteine and glycine-rich protein 2 & 1.741 \\
\hline 586 & BCAT1 & Branched chain aminotransferase 1 , cytosolic & 1.736 \\
\hline 22795 & NID2 & Nidogen 2 (Osteonidogen) & 1.733 \\
\hline 5360 & PLTP & Phospholipid transfer protein & 1.683 \\
\hline 23157 & SEPT 6 & Septin 6 & 1.656 \\
\hline 23231 & KIAA0746 & KIAA0746 Protein & 1.651 \\
\hline 126393 & HSPB6 & Heat shock protein, alpha-crystallin-related, b6 & 1.645 \\
\hline 1462 & CSPG2 & Chondroitin sulfate proteoglycan 2 (versican) & 1.626 \\
\hline 1028 & CDKN1C & Cyclin-dependent kinase inhibitor 1c (p57, kip2) & 1.596 \\
\hline 347733 & TUBB2B & Tubulin, beta $2 \mathrm{~B}$ & 1.575 \\
\hline 9843 & HEPH & Hephaestin & 1.570 \\
\hline 7373 & COL14A1 & Collagen, type xiv, alpha 1 (undulin) & 1.559 \\
\hline 9865 & KIAA0644 & KIAA0644 gene product & 1.550 \\
\hline 10154 & PLXNC1 & Plexin $\mathrm{C} 1$ & 1.546 \\
\hline 5157 & PDGFRL & Platelet-derived growth factor receptor-like & 1.525 \\
\hline 5997 & RGS2 & Regulator of g-protein signalling 2, 24KDA & 1.513 \\
\hline 10403 & KNTC2 & Kinetochore associated 2 & -1.507 \\
\hline 1846 & DUSP4 & Dual specificity phosphatase 4 & -1.521 \\
\hline 25945 & PVRL3 & Poliovirus receptor-related 3 & -1.536 \\
\hline 1474 & CST6 & Cystatin E/M & -1.542 \\
\hline 202 & AIM1 & Absent in melanoma 1 & -1.549 \\
\hline 9975 & NR1D2 & Nuclear receptor sub-family 1 , group d, member 2 & -1.551 \\
\hline 3600 & IL15 & Interleukin 15 & -1.577 \\
\hline 4312 & MMP1 & Matrix metallopeptidase 1 (interstitial collagenase) & -1.626 \\
\hline 891 & CCNB1 & Cyclin B1 & -1.626 \\
\hline 4907 & NT5E & 5'-Nucleotidase, ECTO (CD73) & -1.627 \\
\hline 133 & ADM & Adrenomedullin & -1.654 \\
\hline 2922 & GRP & Gastrin-releasing peptide & -1.679 \\
\hline 9123 & SLC16A3 & Solute carrier family 16 , member 3 & -1.680 \\
\hline 4603 & MYBL1 & V-MYB myeloblastosis viral oncogene homolog like 1 & -1.699 \\
\hline 2199 & FBLN2 & Fibulin 2 & -1.704 \\
\hline 1346 & COX7A1 & Cytochrome c oxidase subunit viia polypeptide 1 (muscle) & -1.704 \\
\hline 358 & AQP1 & Aquaporin 1 & -1.725 \\
\hline 22885 & ABLIM3 & Actin binding lim protein family, member 3 & -1.782 \\
\hline 960 & CD44 & CD44 antigen (indian blood group) & -1.821 \\
\hline 1410 & CRYAB & Crystallin, alpha B & -1.824 \\
\hline
\end{tabular}


Table 2 (continued)

\begin{tabular}{|c|c|c|c|}
\hline Entrez gene ID & Gene symbol & Gene name & Fold increase (expressed in $\log _{2}$ ) \\
\hline 5420 & PODXL & Podocalyxin-like & -1.830 \\
\hline 1805 & DPT & Dermatopontin & -1.841 \\
\hline 9411 & ARHGAP29 & RHO gtpase activating protein 29 & -1.863 \\
\hline 490 & ATP2B1 & ATPASE, CA++ transporting, plasma membrane 1 & -1.880 \\
\hline 7035 & TFPI & Tissue factor pathway inhibitor & -1.884 \\
\hline 1033 & CDKN3 & Cyclin-dependent kinase inhibitor 3 & -1.885 \\
\hline 857 & CAV1 & Caveolin 1 , caveolae protein, $22 \mathrm{KDA}$ & -1.921 \\
\hline 347 & APOD & Apolipoprotein D & -1.931 \\
\hline 11098 & PRSS23 & Protease, serine, 23 & -1.976 \\
\hline 25976 & TIPARP & Tcdd-inducible poly(ADP-RIBOSE) polymerase & -1.979 \\
\hline 1012 & $\mathrm{CDH} 13$ & Cadherin 13, H-cadheriN & -1.987 \\
\hline 1842 & ECM2 & Extracellular matrix protein 2 & -2.004 \\
\hline 858 & CAV2 & Caveolin 2 & -2.025 \\
\hline 8781 & PSPHL & Phosphoserine phosphatase-like & -2.028 \\
\hline 3134 & HLA-F & Major histocompatibility complex, class I, F & -2.043 \\
\hline 3490 & IGFBP7 & Insulin-like growth factor binding protein 7 & -2.062 \\
\hline 8714 & АВCC3 & ATP-binding cassette, sub-family C & -2.080 \\
\hline 9404 & LPXN & Leupaxin & -2.102 \\
\hline 3037 & HAS2 & Hyaluronan synthase 2 & -2.147 \\
\hline 4223 & MEOX2 & Mesenchyme homeobox 2 & -2.156 \\
\hline 4885 & NPTX2 & Neuronal pentraxin ii & -2.162 \\
\hline 290 & ANPEP & Alanyl aminopeptidase & -2.242 \\
\hline 10974 & C10orf116 & Chromosome 10 open reading frame 116 & -2.270 \\
\hline 26872 & STEAP1 & Six transmembrane epithelial antigen of the prostate 1 & -2.284 \\
\hline 3115 & HLA-DPB1 & Major histocompatibility complex, class ii, dp beta 1 & -2.331 \\
\hline 1728 & NQO1 & Nad(P)H dehydrogenase, quinone 1 & -2.336 \\
\hline 9023 & $\mathrm{CH} 25 \mathrm{H}$ & Cholesterol 25-hydroxylase & -2.392 \\
\hline 1396 & CRIP1 & Cysteine-rich protein 1 (intestinal) & -2.421 \\
\hline 11075 & STMN2 & Stathmin-like 2 & -2.433 \\
\hline 5678 & PSG9 & Pregnancy specific beta-1-glycoprotein 9 & -2.569 \\
\hline 5730 & PTGDS & Prostaglandin d 2 synthase $21 \mathrm{kda}$ (brain) & -2.620 \\
\hline 8839 & WISP2 & Wnt1 inducible signaling pathway protein 2 & -2.825 \\
\hline 25907 & RIS1 & RAS-induced senescence 1 & -2.848 \\
\hline 8644 & AKR1C3 & ALDO-keto reductase family 1 , member $\mathrm{C} 3$ & -2.976 \\
\hline 4314 & MMP3 & Matrix metallopeptidase 3 (stromelysin 1 , progelatinase) & -3.130 \\
\hline 131578 & LRRC15 & Leucine rich repeat containing 15 & -3.163 \\
\hline 9976 & CLEC2B & C-type lectin domain family 2 , member B & -3.258 \\
\hline 6275 & S100A4 & S100 calcium binding protein $\mathrm{A} 4$ & -3.458 \\
\hline 7545 & ZIC1 & ZIC family member 1 & -4.051 \\
\hline 3625 & INHBB & Inhibin, beta $b$ & -4.292 \\
\hline 1311 & COMP & Cartilage oligomeric matrix protein & -4.665 \\
\hline 4982 & TNFRSF11B & Tumor necrosis factor receptor superfamily, member 11B & -4.712 \\
\hline
\end{tabular}

50 pathways were obtained. Within these pathways an average of only 1.76 genes were found to be included related to allograft rejection, focal adhesion, TGF- $\beta$ signaling pathway and cytokinecytokine receptor interaction. As there were very few genes for any one pathway, it was difficult to interpret the implication.

\subsection{Gene expression analysis by real time PCR}

RT-PCR was used to verify findings in the gene microarray expression analysis of eight up-regulated and four down-regulated selected genes. Gene expression was assessed relative to the control gene $\beta$-Actin in the cells of the microarray analysis. Mean values for the relative expression of selected genes and magnitudes of upward or downward changes detected by RT-PCR are shown in Table 4 , as well as the fold differences obtained in the microarray study. The expression levels of these genes were consistent with the two techniques.

\section{Discussion}

In the clinical setting, we have seen practical advantages of fetal cell therapy applied to preliminary patients with chronic wounds (Ramelet et al., 2001). The cells are able to exert promoting effects on adhesion, proliferation and migration of existing cells as the repaired wounds tend to heal gradually and the skin is much less atrophic. Also, the pain alleviation following fetal construct application was universal. In other studies using other autologous and allogenous grafting techniques (Khachemoune et al., 2002) alleviation of pain was reported after several applications or days when closer to healing was seen whereas in all of our patients it was seen after application of the first fetal construct. Obvious practical advantages of the fetal skin construct technique are that it is non-invasive and therefore surgical facilities are not necessary. The method is easily applied in an ambulatory manor and the cells are available right away instead of 4-6 weeks with traditional auto-graft techniques. Similar to what we have seen in severe burns, fetal skin constructs are showing promising results also for chronic wound management and promoting an increased quality-of-life for these patients. Leg ulcers are multifactor in cause and associated inflammation, fibrosis and pain make the recalcitrant ulcer difficult to manage. There are also differences between males and females as it is well accepted that hormones have a major impact on regulation of wound repair and it has been further shown that estrogen can inhibit local inflammatory responses by downregulation of macrophage inhibitory factor and thus improved tissue repair seen (Ashcroft et al., 2003; Gulliver et al., in press). Treatment of venous leg ulcers requires commitment and cooperation between the patient and the care provider. It is important to identify health-related quality-of-life factors (i.e. pain, itching, loss of sleep, functional limitations) as many patients feel that related symptoms are overlooked by doctors and thus can delay overall healing (Chaby et al., 2006; Kahn et al., 2004). The impact of this and other complications of venous leg ulcers on overall health and quality-of-life is only beginning to be appreciated. New biolog- 
Table 3

Microarray analysis sumary of significantly different genes: fetal vs old.

\begin{tabular}{|c|c|c|c|}
\hline Gene Ontology & Number of genes differentially expressed (>1.5-fold) & Up-regulated in fetal cells & Percent up-regulated genes in fetal cells (\%) \\
\hline Total & 116 & 54 & 47 \\
\hline Apoptosis & 5 & 4 & 80 \\
\hline Cell adhesion & 13 & 5 & 38 \\
\hline Cell-cell signaling & 25 & 9 & 28 \\
\hline Extracellular matrix & 15 & 9 & 60 \\
\hline Transcription factor & 5 & 1 & 20 \\
\hline Cytokine activity & 5 & 2 & 40 \\
\hline Immune response & 4 & 0 & 0 \\
\hline
\end{tabular}

Entrez gene ID

Gene symbol

Gene name

Fold increase

Cell-cell signaling

5947

4781

114882

10643

8492

9249

5179

126393

347733

9975

3600

4312

4907

133

1346

1410

11098

25976

4223

4885

1728

5730

8644

4314

3625

Apoptosis

1191

5740

7052

2149

4982

Cell adhesion

1000

22795

1462

7373

10154

960

5420

1805

1012

1842

9404

8839

1311

Extracellular matrix

2202

7052

2331

2201

2239

2719

22795

1462

7373

4312

2199

1805

1842

4314

1311
RBP1

NFIB

OSBPL8

IGF2BP3

PRSS12

DHRS3

PENK

HSPB6

TUBB2B

NR1D2

IL15

MMP1

NT5E

ADM

COX7A1

CRYAB

PRSS23

TIPARP

MEOX2

NPTX2

NQO1

PTGDS

AKR1C3

MMP3

INHBB

CLU

PTGIS

TGM2

F2R

TNFRSF11B

CDH2

NID2

CSPG2

COL14A1

PLXNC1

CD44

PODXL

DPT

CDH13

ECM2

LPXN

WISP2

COMP

EFEMP-1

TGM2

FMOD

FBN2

GPC4

GPC3

NID2

CSPG2

COL14A1

MMP1

FBLN2

DPT

ECM2

MMP3

COMP
Retinol binding protein 1, cellular

Nuclear factor I/B $\quad 2.508$

Oxysterol binding protein-like 8

Insulin-like growth factor 2 mrna binding protein 3

Protease, serine, 12 (neurotrypsin, motopsin) $\quad 2.124$

Dehydrogenase/reductase (sdr family) member 3

Proenkephalin $\quad 1.782$

Heat shock protein, alpha-crystallin-related, B6

Tubulin, beta 2B

Nuclear receptor subfamily 1 , group D, member $2 \quad-1.551$

$-1.577$

Matrix metallopeptidase 1 (interstitial collagenase) $\quad-1.626$

5'-nucleotidase, ECTO (CD73)

Adrenomedullin

Cytochrome C oxidase subunit viia polypeptide 1 (muscle) $\quad-1.704$

Crystallin, alpha B

Protease, serine, 23

TCDD-inducible poly(adp-ribose) polymerase

Mesenchyme homeobox 2

Neuronal pentraxin II

$\mathrm{Nad}(\mathrm{P}) \mathrm{H}$ dehydrogenase, quinone 1

Prostaglandin D2 synthase 21KDA (brain)

Aldo-keto reductase family 1 , member $\mathrm{C} 3$

Matrix metallopeptidase 3 (stromelysin 1, progelatinase)

Inhibin, beta $\mathrm{B}$

$-1.824$

$-1.976$

$-1.979$

$-2.156$

$-2.162$

$-2.336$

$-2.620$

$-2.976$

$-3.130$

$-4.292$

Clusterin

3.511

Prostaglandin i2 (prostacyclin) synthase

3.209

2.657

2.345

Coagulation factor ii (thrombin) receptor

$-4.712$

Cadherin 2, type 1, n-cadherin

2.038

Nidogen 2 (osteonidogen)

Chondroitin sulfate proteoglycan 2 (versican)

1.733

1.626

1.559

Plexin $\mathrm{C} 1$

CD44 antigen (Indian blood group)

Podocalyxin-like

Dermatopontin

Cadherin 13, H-cadherin

1.546

$-1.821$

$-1.830$

$-1.841$

$-1.987$

$-2.004$

Extracellular matrix protein 2

$-2.102$

$-2.825$

Wnt1 inducible signaling pathway protein 2

$-4.665$

EGF-containing fibulin-like extracellular matrix protein 1

4.041

Transglutaminase 2

2.657

Fibromodulin

2.457

2.034

2.034

Glypican 4

Glypican 3

2.021

1.733

Chondroitin sulfate proteoglycan 2 (versican)

1.626
1.559

$-1.626$

$-1.704$

$-1.841$

$-2.004$

$-3.130$

$-4.665$ 
Table 3 (continued)

\begin{tabular}{|c|c|c|c|}
\hline Entrez gene ID & Gene symbol & Gene name & Fold increase \\
\hline \multicolumn{4}{|c|}{ Transcription factor } \\
\hline 11336 & NFIB & Nuclear factor I/B & 2.508 \\
\hline 5760 & NR1D2 & Nuclear receptor subfamily 1 , group D, member 2 & -1.551 \\
\hline 673 & MYBL1 & V-MYB myeloblastosis viral oncogene homolog-like1 & -1.699 \\
\hline 10496 & MEOX2 & Mesenchyme homeobox 2 & -2.156 \\
\hline \multicolumn{4}{|l|}{ Immune response } \\
\hline 3600 & IL15 & Interleukin 15 & -1.577 \\
\hline 3134 & HLA-F & Major histocompatibility complex, class I, F & -2.043 \\
\hline 3115 & HLA-DPB1 & Major histocompatibility complex, class II, DP beta 1 & -2.331 \\
\hline 1396 & CRIP1 & Cysteine-rich protein 1 (intestinal) & -2.421 \\
\hline 9976 & CLEC2B & C-type lectin domain family 2 , member B & -3.258 \\
\hline \multicolumn{4}{|l|}{ Cytokine activity } \\
\hline 5764 & PTN & Pleiotrophin (heparin binding growth factor 8 , neurite growth-promoting factor 1 ) & 3.050 \\
\hline 4192 & MDK & Midkine (neurite growth-promoting factor 2) & 2.579 \\
\hline 3600 & IL15 & Interleukin 15 & -1.577 \\
\hline 3625 & INHBB & Inhibin, beta b (activin ab beta polypeptide) & -4.292 \\
\hline 4982 & TNFRSF11B & Tumor necrosis factor receptor superfamily, member 11b (osteoprotegerin) & -4.712 \\
\hline
\end{tabular}

ical techniques may be of high interest if the safety and simplicity can be assured. Nevertheless, a search for improvement of wound healing therapies which can improve inflammation, pain management and long-term closure is necessary for patient management and their quality-of-life. Cell therapies and tissue engineering are showing great promise in wound management. The cell choice is therefore an important factor for simplifying the overall technique and bringing therapy rapidly to the patient.

The precise mechanisms of efficient wound healing remain unknown despite the great increase in knowledge gained over the past decade although fetal wound repair is a tightly regulated process involving many cellular mediators. Chen et al. (2007) have proposed that understanding the "blueprint of fetal skin repair" might allow the manipulation of adult wound healing in order to decrease scarring and fibrosis. There are indeed many genes that are significantly different in the "fetal skin blueprint" when compared to older skin that we have elucidated herein with banked fetal and old dermal skin cells. These factors taken together and presented in a cellular therapy seem to be an interesting approach for chronic wounds.

We have seen major differences in gene families of banked fetal dermal skin cells compared to old skin cells banked in the same manner. Profiles that are predominant are in the families of genes in cell adhesion and extracellular matrix, cell-cell signaling and immune response confirmed that our molecular data obtained by

Table 4

Comparison of real time pcr to microarray analysis.

\begin{tabular}{lcc}
\hline & Relative gene expression MA & $\begin{array}{l}\text { Relative gene expression real time } \\
(-\mathrm{ddcT})\end{array}$ \\
\hline Gene symbol & & \\
RBP1 & 3.91 & $7.35 \pm 0.97$ \\
PTN & 3.05 & $0.12 \pm 0.36$ \\
MDK & 2.57 & $1.9 \pm 0.29$ \\
FMOD & 2.45 & $2.86 \pm 0.89$ \\
CDKN1C & 1.59 & $4.59 \pm 0.29$ \\
GDF10 & 0.25 & $1.45 \pm 0.24$ \\
BMP6 & -0.43 & $2.21 \pm 0.47$ \\
MMP14 & -0.63 & $1.64 \pm 0.53$ \\
MMP1 & -1.62 & $1.41 \pm 0.19$ \\
DPT & -1.81 & $-3.82 \pm 0.26$ \\
HLA-DPB1 & -2.33 & $-16.95 \pm 1.82$ \\
MMP3 & -3.13 & $-4.36 \pm 0.59$ \\
INBHH & -4.29 & $-5.70 \pm 0.14$ \\
TNFRSF11B & -4.71 & $-6.73 \pm 0.24$ \\
\hline
\end{tabular}

microarray were consistent with the published biochemical and clinical findings related to efficient fetal tissue repair.

In our microarray data, significant increases were seen in matrix proteins such as fibromodulin (FMOD) and collagens compared to old cells and these data correspond to the literature (Mast et al., 1993; Hallock et al., 1993; Soo et al., 2000, 2002). FMOD was also significantly higher in the RT-PCR which was one of the random probes selected for confirmation of the microarray data. Genes above and below the established curve from our statistical analysis were chosen for this conformational purpose only. The most significantly expressed gene in the microarray data, EFEMP-1 or Fibulin 3 (FPLN-3) is homologous to FBLN-5 and are widely expressed ECM proteins known to regulate cell proliferation and have also been shown to antagonize angiogenesis. FBLN-5 has been shown to promote wound healing in vivo using a retroviral gene transfer to dermal wounds of rabbits showing 50\% net increase of newly formed granulation tissue and wound closure (Lee et al., 2004; Albig et al., 2006; Soo et al., 2000). Microarray analysis has also shown the importance of ECM glypicans which are proteins that can bind a multitude of GF and ECM molecules which are implicated in signal transduction cascaded that most likely regulate cell proliferation. Glypicans activate or determine activities of morphogens and GF such as FGF, BMPs and IGFs (Berry et al., 1998; De Cat and David, 2001; Hwang et al., 2001). We have seen that glycipans are up-regulated in fetal dermal skin cells (microarray data, GPC4 and GPC3 with 2.02 and 2.03 up-regulated, respectively) and in another recent study by Lener et al. (2006) they had seen the same effect with down-regulation of glycipans in aged skin. Many genes in the ECM family can therefore interact with other gene families to regulate cell growth, angiogenesis and migration. Migration is an important fibroblast response following tissue injury and is crucial to the repair process. Fetal fibroblasts possess more rapid intrinsic rates of migration than that seen in adult skin fibroblasts (Sandulache et al., 2005; Sandulache et al., 2007).

Cell-cell signaling genes are related to cell growth characteristics, differentiation and development of tissues and therefore important for fetal dermal skin cells. In the microarray data, Retinol binding Protein 1 (RBP1, gene encoding the carrier protein for transport of vitamin A) which is necessary for growth and differentiation of epithelial tissues was 3.9-fold increased in fetal dermal skin cells and confirmation with RT-PCR at 6.45-fold higher expression. Others such as Tubulin beta $2 \mathrm{~B}$ (up-regulated at 1.58) have been shown to be highly present in fetal brain development (Nakamura et al. 2003). 
Other studies emphasize that wound healing is regulated by many cytokines, growth factors and their receptors (Constant et al., 1997; Peled et al., 2001; Werner and Grose, 2003; Yang et al., 2003) and it is suggested that efficient wound healing in fetal skin at early gestation is a result of the unique cytokine or growth factor profile. Of these, transforming growth factors-beta (TGF- $\beta$ ) has been most widely studied and there are three highly homologous TGF- $\beta$ isoforms known in humans: $\beta 1, \beta 2$ and $\beta 3$. Published studies have shown that it is the relative proportion of TGF- $\beta$ isoforms, and not the absolute concentration of any one isoform which determines the wound repair outcome; however, other studies question the efficacy of different isoforms (TGF- $\beta 3$ ) in wound healing (Sullivan et al., 1993; Vooijs et al., 2004; Wu et al., 1997; Krummel et al., 1988; Lin et al, 1995) and we have not seen a preponderant expression of these isoforms except for TGF- $\beta 2$ with 6 -fold up-regulation in fetal cells in a previous study analysis with RT-PCR (Hirt-Burri et al., 2008). This suggests that factors other than TGF- $\beta$ may also be important in efficient repair. In our microarray data, TGF- $\beta$ superfamily genes such as Inhibin (INHBB) and Cartilage oligomeric matrix protein (COMP) were significantly different in fetal dermal skin cells (INHBB, microarray with -4.292; COMP, microarray with -4.665). Also, known to modulate TGF- $\beta$ activity, ECM constituents such as fibromodulin or decorin are expressed as a function of gestation age in fetal skin (Beanes et al., 2001). This supports the hypothesis that differential expression of TGF- $\beta$ isoforms and TGF- $\beta$ activity modulators, rather than the mere presence or absence of TGF- $\beta$ has a role in the regulation of efficient repair.

An increased stimulus for angiogenesis and vascular permeability may assist the rapid healing of wounds. Studies have shown evidence for the importance of angiogenesis in wound repair. Pleiotropin (PTN), a cytokine inducing heparin-binding/differentiation, is certain to have a major role in angiogenesis in wound healing and can induce formation of functional neovaculature in vivo. Midkine (MDK), which has 50\% amino acid sequence identity and striking domain homology to that of PTN are the two members of the PTN/MDK developmental gene family (Christman et al., 2005). Both PTN and MDK were shown to be significantly increased in fetal compared to adult skin with fold increase of 3.05 and 2.57, respectively.

Not unexpected, genes involved in immune response were all down-regulated in fetal dermal skin cells with five such genes within the microarray. Among these genes highly implicated in allograft rejection, include transplantation antigen Major Histocompatibility Complex of Class I (HLA-F, microarray with -2.043) and Class II (HLA-DPB1, microarray with -2.331).

In all, fetal skin constructs show promise for treatment of acute and chronic wounds as banked cells can be thoroughly screened for unwanted virus and pathogen. Multiple treatments with fetal cell constructs in an out-patient setting were well tolerated and positive effects of anti-inflammatory and anti-pain were evident. Expression profiling of banked fetal dermal skin cells compared to aged dermal skin cells has provided biological grouping of important gene families implicated in the mechanism of wound repair. Indeed, individual growth factors (TGF- $\beta 2$, TGF- $\beta 3$, IL-10, PDGF) have been shown in the clinic to help in different aspects of overall wound healing but it is a very complex process (Adzick and Lorenz, 1994). Most likely, many factors taken together are necessary for complete wound closure which could indeed be offered by a cell-based therapy for chronic wound management.

\section{Acknowledgments}

The authors wish to thank Baxter (Switzerland) for the donation of the matrix (TissueFleece ${ }^{\circledR}$ ) for these studies. We also thank Drs. Zwahlen and Poussin for helpful discussions on micro-array analy- sis. These studies were supported by the Foundation for Orthopedics for Swiss Romande and a grant from Nestlé (Switzerland) for working on aging.

\section{References}

Albig, A.R., Neil, J.R., Schiemann, W.P., 2006. Fibulins 3 and 5 antagonize antiogenesis in vivo. Cancer Res. 66 (5), 2621-2629.

Adzick, N.S., Lorenz, H.P., 1994. Cells, matrix, growth factors and the surgeon: the biology of scarless fetal wound repair. Ann. Surg. 220, 10-18.

Armstrong, J.R., Ferguson, M.W.J., 1995. Ontogeny of the skin and the transition from scar free to scarring phenotype during wound healing in the pouch young of the marsupial Monodelphis domestica. Dev. Biol. 169, 242-260.

Ashcroft, G.S., Mills, S.J., Lei, K., Gibbons, L., Jeong, M.-J., Taniguchi, M., Burow, M., Horan, M.A., Wahl, S.M., Nakayama, T., 2003. Estrogen modulates cutaneous wound healing by downregulating macrophage migration inhibitory factor. J. Clin. Invest. 111, 1309-1318.

Beanes, S.R., Dang, C., Soo, C., Wang, Y., Urata, M., Ting, K., Fonkalsrud, E.W., Benhaim, P., Hedrick, M.H., Atkinson, J.B., Lorenz, H.P., 2001. Down-regulation of decorin, a transforming growth factor-beta modulator, is associated with scarless fetal wound healing. J. Pediatr. Surg. 36, 1666-1671.

Beanes, S.R., Hu, F.Y., Soo, C., Dang, C.M., Urata, M., Ting, K., Atkinson, J.B., Benhaim, P., Hedrick, M.H., Lorenz, H.P., 2002. Confocal microscopic analysis of scarless repair in the fetal rat: defining the transition. Plast. Reconstr. Surg. 109, 160170.

Berry, D., Harding, K.G., Stanton, M.R., Jasani, B., Ehrlich, H.P., 1998. Human wound contraction: collagen organization, fibroblasts, and myofibroblasts. Plast. Reconstr. Surg. 102, 124-131.

Booza, C., Munoz, A., Amate, J.M., 2005. Efficacy of modern dressings in the treatment of leg ulcers: a systematic review. Wound Rep. Reg. 13, 218-229.

Bullard, K.M., Longaker, M.T., Lorenz, H.P., 2003. Fetal wound healing: current biology. World J. Surg. 27, 54-61.

Caravaggi, C., De Giglio, R., Pritelli, C., Sommaria, M., Dalla Noce, S., Faglia, E., Mantero, M., Clerici, G., Fratino, P., Dalla Paola, L., Mariani, G., Mingardi, R., Morabito, A., 2003. HYAFF 1-based autologous dermal and epidermal grafts in the treatment of noninfected diabetic plantar and dorsal foot ulcers. Diabetes Care 26, 2853-2859.

Cass, D.L., Meuli, M., Adzick, N.S., 1997. Scar wars: implications of fetal wound healing for the pediatric burn patient. Pediatr. Surg. 12, 484-489.

Cavallini, M., 2007. Autologous fibroblasts to treat deep and complicated leg ulcers in diabetic patients. Wound Rep. Reg. 15, 35-38.

Chaby, G., Viseux, V., Ramelet, A.A., Ganry, O., Billet, A., Lok, C., 2006. Refractory venous or arteriovenous leg ulcers: a multifactorial origin. Dermatol. Surg. 32, 512-519.

Chen, W., Fu, X., Ge, S., Sun, T., Zhou, G., Han, B., Li, H., Sheng, Z., 2007. Profiling of genes differentially expressed in a rat of early and later gestational ages with high-density oligonuclotide DNA array. Wound Rep. Regen. 15, 147-155.

Christman, K.L., Fang, Q., Kim, A.J., Sievers, R.E., Fok, H.H., Candia, A.F., Colley, K.J., Herradon, G., Ezquerra, L., Deuel, T.F., Lee, R.J., 2005. Pleiotrophin induces formation of functional neovaculature in vivo. Biochem. Biophys. Res. Commun. 332, 1146-1152.

Constant, J.S., Bullard, K.M., Hunt, T.K., Longaker, M.T., 1997. Increased vascular endothelial growth factor in hypoxic fetal wounds. Surg. Forum 48, 519-521.

Dang, C., Ting, K., Soo, C., Longaker, M.T., Lorenz, H.P., 2003. Fetal wound healing current perspectives. Clin. Plast. Surg. 30, 13-23.

de Buys Roessingh, A., Hohlfeld, J., Scaletta, C., Hirt-Burri, N., Gerber, S., Hohlfeld, P., Applegate, L.A., 2006. Development and Characterization of a fetal skin bank for tissue engineering and its clinical application for acute and chronic wounds. Cell Transplant. 15, 823-834.

De Cat, B., David, G., 2001. Developmental roles of the glypicans. Cell Develop. Biol. 12, 117-125.

Dennis Jr., G., Sherman, B.T., Hosack, D.A., Yang, J., Gao, W., Lane, H.C., Lempicki, R.A., 2003. DAVID: database for annotation, visualization, and integrated discovery. Genome Biol. 4 (5), P3.

Eklöf, B., Rutherford, R.B., Bergan, J.J., Carpentier, P.H., Gloviczki, P., Kistner, R.L., Meissner, M.H., Moneta, G.L., Myers, K., Padberg, F.T., Perrin, M., Vaughan Ruckley, C., Coleridge Smith, P., Wakefield, T.W.for the American Venous Forum International Ad Hoc Committee for Revision of the CEAP Classification, Helsingborg, Sweden, 2004. Revision of the CEAP classification for chronic venous disorders: consensus statement. J. Vasc. Surg. 40, 1248-1252.

Falanga, V., Margolis, D., Alvarez, O., Auletta, M., Maggiacomo, F., Altman, M., Jensen, J., Sabolinski, M., Hardin-Young, J.the Human Skin Equivalent Investigators Group, 1998. Rapid healing of venous ulcers and lack of clinical rejection with an allogeneic cultured human skin equivalent. Arch. Dermatol. 134, 293-300.

Gulliver, S.C., Ruckshanthi, J.P.D., Hardman, M.J., Nakayama, T., Ashcroft, G.S., in press. Sex dimorphism in wound healing: the roles of sex steroids and macrophage migration inhibitory factor. Endocrinology, 10.1210/en.2008-0355.

Hafner, J., Ramelet, A.A., Schmeller, W., Brunner, U., 1999. Management of leg ulcers. Curr. Prob. Dermatol. 27, 4-7.

Hallock, G.G., Merkel, J.R., Rice, D.C., DiPaolo, B.R., 1993. The ontogenetic transition of collagen deposition in rat skin. Ann. Plast. Surg. 30, 239-243.

Hirt-Burri, N., Scaletta, C., Gerber, S., Pioletti, D., Applegate, L.A., 2008. Woundhealing gene family expression differences between fetal and foreskin cells used for bioengineered skin substitutes. Artif. Organs 32, 509-518. 
Hohlfeld, J., De Buys Roessingh, A., Hirt-Burri, N., Chaubert, P., Gerber, S., Scaletta, C., Hohlfeld, P., Applegate, L.A., 2005. Tissue engineered fetal skin constructs for paediatric burns. Lancet 366, 840-842.

Hwang, E.A., Lee, H.-B., Tark, K.C., 2001. Comparison of bone morphogenic protein receptors expression in the fetal and adult skin. Yonsei Med. J. 42, 581-586.

Kahn, S.R., M'Ian, C.E., Lamping, D.L., Kurtz, X., Berard, A., Abenhaim, L.A., 2004. Relationship between clinical classification of chronic venous disease and patient-reported quality of life: Results from an international cohort study. J. Vasc. Surg. 39, 823-828.

Khachemoune, A., Bello, Y.M., Phillips, T.J., 2002. Factors that influence healing in chronic venous ulcers treated with crypreserved human epidermal cultures. Dermatol. Surg. 28, 274-280.

Krummel, T.M., Michna, B.A., Thomas, B.L., Sporn, M.B., Nelson, J.M., Salzberg, A.M., Cohen, I.K., Diegelmann, R.F., 1988. Transforming growth factor beta (TGF-beta) induces fibrosis in a fetal wound model. J. Pediatr. Surg. 23, 647-652.

Lee, J.J., Roy, N., Mogford, J.E., Schiemann, W.P., Mustoe, T.A., 2004. Fibulin-5 promotes wound healing in vivo. J. Am. Coll. Surg. 199, 403-410.

Lener, T., Moll, P.R., Rinnerthaler, M., Bauer, J., Aberger, F., Richter, K., 2006. Expression profiling of aging in the human skin. Exp. Gerontol. 41, 387-397.

Limat, A., Mauri, D., Hunziker, T., 1996. Successful treatment of chronic leg ulcers with epidermal equivalents generated from cultured autologous outer root sheath cells. J. Invest. Dermatol. 107, 128-135.

Lin, R.Y., Sullivan, K.M., Argenta, P.A., Meuli, M., Lorenz, H.P., Adzick, N.S., 1995. Exogenous transforming growth factor-beta amplifies its own expression and induces scar formation in a model of human fetal skin repair. Ann. Surg. 222, $146-154$.

Livak, K.J., Schmittgen, T.D., 2001. Analysis of relative gene expression data using real-time quantitative PCR and the $2^{-\Delta \Delta C T}$ method. Methods $25,402-408$.

Lorenz, H.P., Lin, R.Y., Longaker, M.T., Whitby, D.J., Adzick, N.S., 1995. The fetal fibroblast: the effector cell of scarless fetal skin repair. Plast. Reconstr. Surg. 96, 1251-1259. discussion 1260-1251.

Mansourian, R., Mutch, D.M., Antille, N., Aubert, J., Fogel, P., Le Goff, J.M., Moulin, J., Petrov, A., Rytz, A., Voegel, J.J., Roberts, M.A., 2004. The Global Error Assessment (GEA) model for the selection of differentially expressed genes in microarray data. Bioinformatics 20, 2726-2737.

Marklund, B., Sülau, T., Lindholm, C., 2000. Prevalence of non-healed and healed chronic leg ulcers in an elderly rural population. Scan. J. Health Care 18, 58-60.

Marston, W.A., Hanft, J., Noorwood, P., Pollak, P., 2003. Dermagraft Diabetic Foot Ulcer Study Group. The efficacy and safety of Dermagraft in improving the healing of chronic diabetic foot ulcers: results of a prospective randomized trial. Diabetes Care 26, 1701-1705.

Mast, B.A., Diegelmann, R.F., Krummel, T.M., Cohen, I.K., 1993. Hyaluronic acid modulates proliferation, collagen and protein synthesis of cultured fetal fibroblasts. Matrix 13, 441-446.

Mutch, D.M., Berger, A., Mansourian, R., Rytz, A., Roberts, M.A., 2002. The limit fold change model: a practical approach for selecting differentially expressed genes from microarray data. BMC Bioinform. 3, 17.
Nakamura, N., Yamamoto, M., Oda, E., Yamamoto, A., Kanemura, Y., Hara, M., Suzuki, A., Yamasaki, M., Okano, H., 2003. Expression of tubulin beta II in neural stem/ progenitor cells and radial fibers during human fetal brain development. Lab Invest. 83, 479-489.

Peled, Z.M., Rhee, S.J., Hsu, M., Chang, J., Krummel, T.M., Longaker, M.T., 2001. The ontogeny of scarless healing II: EGF and PDGF-B gene expression in fetal rat skin and fibroblasts as a function of gestational age. Ann. Plast. Surg. 47, 417-424.

Quintin, A., Hirt-Burri, N., Scaletta, C., Schizas, C., Pioletti, D., Applegate, L.A., 2007. Consistency and safety of fetal cell banks for research and clinical use: preliminary analysis of fetal skin banks. Cell Transplant. 16, 675-684.

Ragnarson, T.G., Hjelmgren, J., 2005. Annual costs of treatment for venous leg ulcers in Sweden and the United Kingdom. Wound Repair Regen. 13, 13-18.

Ramelet, A.-A., Scaletta, C., Rocque, S., Hohlfeld, P., Burri, N., Applegate, L.A., 2001 Three-Dimensional Cutaneous Tissue Engineering for the Treatment of Acute and Chronic Wounds. Dermatology 203, 89-107.

Sandulache, V.C., Dohar, J.E., Hebda, P.A., 2005. Adult-fetal fibroblast interactions: effects on cell migration and implications for cell transplantation. Cell Transplant. 14, 331-337.

Sandulache, V.C., Parekh, A., Dohar, J.E., Hebda, P.A., 2007. Fetal dermal fibroblasts retain a hyperactive migratory and contractile phenotype under 2- and 3dimensional constraints compared to normal adult fibroblasts. Tissue Eng. 13 2791-2801.

Soo, C., Hu, F.-Y., Zhang, X., Lorenz, H.P., Hedrick, M.H., Mackool, R.J., Plaas, A., Kim, S.-K., Longaker, M.T., Freymiller, E., Ting, K., 2000. Differential expression of fibromodulin, a transforming growth factor- $\beta$ modulatore, in fetal skin development and scarless repair. Am. J. Path. 157, 423-433.

Soo, C., Sayah, D.N., Zhang, X., Beanes, S.R., Nishimura, I., Dang, C., Freymiller, E., Ting, K., 2002. The identification of novel wound-healing genes through differential display. Plast. Reconstr. Surg. 110, 787-797.

Sullivan, K.M., Lorenz, H.P., Adzick, N.S., 1993. The role of TGFb in human fetal wound healing. Surg. Forum. 44, 625-627.

Uccioli, L., 2003. TissueTech Autograph System Italian Study Group. A clinical investigation of the characteristics and outcomes of treating chronic lower extremity wounds using the tissuetech autograft system. Int. J. Low. Extrem. Wounds 2, 140-151.

Vooijs, D.P., Walboomers, X.F., Parker, J.A., Von den Hoff, J.W., Jansen, J.A., 2004 Transforming growth factor-beta3-loaded microtextured membranes for skin regeneration in dermal wounds. J. Biomed. Mater. Res. 70A, 402-411.

Werner, S., Grose, R., 2003. Regulation of wound healing by growth factors and cytokines. Physiol. Rev. 83, 835-870.

Wu, L., Siddiqui, A., Morris, D.E., Cox, D.A., Roth, S.I., Mustoe, T.A., 1997. Transforming growth factor beta 3 (TGF beta 3 ) accelerates wound healing without alteration of scar prominence. Histologic and competitive reversetranscription-polymerase chain reaction studies. Arch. Surg. 132, 753-760.

Yang, G.P., Lim, I.J., Phan, T.T., Lorenz, H.P., Longaker, M.T., 2003. From scarless fetal wounds to keloids: molecular studies in wound healing. Wound Repair Regen. 11, 411-418. 